\title{
UJI AKTIVITAS ANTIDIABETES DARI EKSTRAK DAUN SESEWANUA (Clerodendron squamatum Vahl.) TERHADAP TIKUS PUTIH JANTAN GALUR WISTAR (Rattus norvegicus L.)
}

\author{
Billy Nathaniel Nangoy ${ }^{1)}$, Edwin de Queljoe ${ }^{2)}$, Adithya Yudistira ${ }^{1)}$ \\ ${ }^{1)}$ Program Studi Farmasi FMIPA UNSRAT Manado, \\ ${ }^{2)}$ Program Studi Biologi FMIPA UNSRAT Manado, 95115
}

\begin{abstract}
Sesewanua leaves contain flavonoids which can be potentially as antidiabetic. Flavonoids reduce blood sugar levels by capturing free radicals that cause damage to pancreatic beta cells and inhibit pancreatic beta cell damage. The purpose of this study was to determine the effect of antidiabetic activity on the administration of Sesewanua (Clerodendron squamatum Vahl.) Leaf extracts in wistar white rats (Rattus norvegicus) induced by Aloxan. This type of research is a laboratory experiment using a completely randomized design. Test animals are grouped into 5 groups each consisting of 3 test animals. The negative control group $(K-)$ was not treated, the positive control group $(K+)$ was given metformin, groups 2, 3, and 4 were treated with different extract concentration of 200, 400, and $800 \mathrm{mg}$. Before the treatment was done the rats were examined the initial blood sugar level, then induced alloxan monohydrate $120 \mathrm{mg} / \mathrm{kg} \mathrm{BW}$ intraperitonially (ip), and checked the blood sugar level on the $3^{\text {rd }}$ day and continued with the administration of the leaf extracts of the animal every two days until the 14 th day. The results showed that sesewanua leaf extracts with a concentration of 200, 400, and 800mg had a decreased activity in blood sugar levels from day 4 to day 14 with a decrease of $13.66 \mathrm{mg} / \mathrm{dL}$ in the concentration group $1,43 \mathrm{mg} / \mathrm{dL}$ in the dose concentration 2, and $103 \mathrm{mg} / \mathrm{dL}$ in the concentration group 3.
\end{abstract}

Keywords: Blood Glucose, Clerodendron squamatum Vahl., Flavonoids, Rattus norvegicus

\begin{abstract}
ABSTRAK
Daun sesewanua mengandung flavonoid yang dapat berpotensi sebagai antidiabetes. Flavonoid menurunkan kadar gula darah dengan cara menangkap radikal bebas penyebab kerusakan sel beta pankreas dan menghambat kerusakan sel beta pankreas. Tujuan penelitian ini adalah mengetahui efek aktivitas antidiabetes terhadap pemberian ekstrak Daun Sesewanua (Clerodendron squamatum Vahl.) pada Tikus Putih Galur Wistar (Rattus norvegicus) yang telah diinduksi Aloksan. Jenis penelitian ini adalah eksperimen laboratorium menggunakan rancangan acak lengkap. Hewan uji dikelompokan dalam 5 kelompok masing-masing terdiri dari 3 ekor hewan uji. Kelompok kontrol negatif (K-) tidak diberi perlakuan, kelompok kontrol positif $(\mathrm{K}+)$ diberikan metformin, Kelompok 2, 3, dan 4 diberi perlakuan dengan konsentras ekstrak yang berbeda-beda yaitu 200, 400, dan $800 \mathrm{mg}$. Sebelum perlakuan dilakukan tikus diperiksa kadar gula darah awal, kemudian diinduksi aloksan monohidrat 120 $\mathrm{mg} / \mathrm{kgBB}$ secara intraperitonial (ip), dan diperiksa kadar gula darah pada hari ke-3 dan dilanjutkan dengan pemberian ekstrak daun sesewanua setiap dua hari sekali sampai hari ke-14. Hasil penelitian menunjukkan bahwa ekstrak daun sesewanua dengan konsentrasi 200, 400 , dan 800mg memiliki aktivitas penurunan kadar gula darah dari hari ke-4 sampai hari ke-14 dengan penurunan sebesar 13.66 $\mathrm{mg} / \mathrm{dL}$ pada kelompok konsentrasi $1,43 \mathrm{mg} / \mathrm{dL}$ pada kelompok konsentrasi 2, dan $103 \mathrm{mg} / \mathrm{dL}$ pada kelompok konsentrasi 3.
\end{abstract}

Kata Kunci: Clerodendron squamatum Vahl., Flavonoid, Glukosa Darah, Rattus norvegicus 


\section{PENDAHULUAN}

Angka kejadian Diabetes Mellitus dari tahun ke tahun terus mengalami peningkatan yang cukup dratis dan memprihatinkan. Menurut data World Health Organization (WHO) tahun 2005 Negara Indonesia menempati peringkat ke4 jumlah penderita diabetes terbanyak di dunia setelah India, China, dan Amerika Serikat. Prevalensinya mencapat 8,6 persen dari total penduduk dan diperkirakan akan terus meningkat mencapai 21,3 juta penderita pada tahun 2030 (Iskandar, 2010).

Diabetes mellitus merupakan kelompok penyakit metabolik yang ditandai dengan meningkatnya kadar glukosa darah di atas nilai normal karena kelainan sekresi insulin, kerja insulin atau keduanya (Perkeni, 2011). Gejala-gejala karakteristik diabetes mellitus meliputi, kehausan berlebihan, polifagi, poliuria, kehilangan berat badan, sering terjadi bisul, gatal di anggota badan, dan impotensi. Pengobatan diabetes mellitus dapat dilakukan secara medis dengan obat-obatan modern dan suntikan tetapi karena tingginya biaya pengobatan cara medis ini terkadang sulit dilakukan. Diabetes Melitus juga dapat diatasi dengan pengobatan alami dengan memanfaatkan tanaman berkhasiat obat. Tanaman berkhasiat obat dapat diperoleh dengan mudah, dapat dipetik langsung untuk pemakaian segar atau dapat dikeringkan. Oleh karena itu, pengobatan tradisional dengan tanaman obat menjadi langkah alternatif untuk mengatasinya (Buraerah, 2010).

Sesewanua

(Clerodendron squamatum Vahl.) secara empiris telah digunakan oleh masyarakat di beberapa daerah di Sulawesi Utara khususnya di wilayah Minahasa untuk mengobati demam, patah tulang, dan penurun bengkak. Daun sesewanua mengandung flavonoid dan alkaloid yang dapat berpotensi sebagai antioksidan (Huliselan, 2015). Metabolit sekunder pada daun sesewanua seperti flavonoid dan alkaloid yang dapat berpotensi sebagai antioksidan serta perbedaan polaritas pelarut yang dapat menghasilkan perbedaan jumlah dan jenis metabolit sekunder.

Flavonoid merupakan pigmen tumbuhan dengan warna kuning, kuning jeruk, dan merah dapat ditemukan pada buah, sayuran, kacang, biji, batang, bunga, herba, rempah-rempah, serta produk pangan dan obat dari tumbuhan seperti minyak zaitun, teh, cokelat, anggur merah, dan obat herbal. Flavonoid juga dikenal sebagai vitamin $\mathrm{P}$ dan citrin, dan merupakan pigmen yang diproduksi oleh sejumlah tanaman sebagai warna pada bunga yang dihasilkan. Bagian tanaman yang bertugas untuk memproduksi flavonoid adalah bagian akar yang dibantu oleh rhizobia, bakteri tanah yang bertugas untuk menjaga dan memperbaiki kandungan nitrogen dalam tanah (Harbone, 1987).

\section{METODOLOGI PENELITIAN}

\section{Alat}

Alat-alat yang digunakan adalah
ayakan 100 mesh, oven(Memmert $\left.{ }^{\circledR}\right)$, Glukometer, sonde oral, dispesible $1 \mathrm{cc}$, batang pengaduk, neraca analitik (Mettler Toledo tipe PL 303, Dragon 205), gelas ukur (Pyrex), beker gelas (Pyrex), kertas saring, sarung tangan, masker, botol sampel, gunting, blender, cawan petri (Pyrex), kandang, tempat makan mencit.

\section{Bahan}

Bahan-bahan yang digunakan adalah tikus putih jantan galur wistar (Rattus novergicus) 15 ekor, daun sesewanua (Clerodendron squamatum Vahl.), aquades, etanol $96 \%$, Aloksan, Metformin, pangan tikus wistar jantan (Rattus novergicus) berupa beras jagung.

\section{Bentuk penelitian}

Jenis penelitian ini adalah eksperimen laboratorium. Menggunakan Rancangan Acak Lengkap (RAL). Hewan uji 
dikelompokan dalam 5 kelompok masingmasing terdiri dari 3 ekor hewan uji. Kelompok 1 tidak diberi perlakuan dan sebagai kontrol negatif. Kelompok 2, 3, dan 4 diberi perlakuan dengan dosis yang berbeda-beda yaitu 200, 400, dan $800 \mathrm{mg}$. Sementara itu kelompok 5 diberi perlakuan dengan dosis metformin $500 \mathrm{mg}$.

\section{Prosedur Kerja}

\section{Pengambilan sampel}

Daun sesewanua diambil dari daerah Amurang Kabupaten Minahasa Selatan.

\section{Preparasi sampel}

Daun sesewanua dicuci dengan air mengalir dan ditiriskan, kemudian dikeringkan dalam oven pada suhu $\pm 40^{\circ} \mathrm{C}$ sampai kadar air $<10 \%$.

\section{Pembuatan ekstrak daun sesewanua}

Sampel daun sesewanua yang sudah menjadi serbuk simplisia ditimbang dan dimasukkan ke dalam cawan petri kemudian diekstraksi menggunakan metode maserasi dengan cara serbuk simplisia direndam dalam pelarut etanol $96 \%$ dan dibiarkan selama 3 hari kemudian disaring menggunakan kertas saring, kemudian ampas dari sampel diremaserasi selama 2 hari. Filtrate lalu diuapkan dengan oven pada suhu $\pm 40^{\circ} \mathrm{C}$ sampai kental.

\section{Penyiapan Hewan Uji}

Tikus putih jantan galur wistar (Rattus norvegicus) sebagai hewan uji yang terbagi atas 5 kelompok di mana masingmasing kelompok terdiri atas 3 ekor tikus putih jantan galur wistar jantan yang dipelihara dalam kandang yang dibuat dari keranjang berisi serbuk kayu dan diberi pakan beras jagung. Hewan coba diaklimatisasi selama kurang lebih 2 minggu sebelum perlakuan.

\section{Pembuatan Larutan Uji}

Pembuatan larutan uji diawali dengan menimbang ekstrak kental daun sesewanua (Clerodendron squamatum Vahl.) sesuai dengan dosis (3.6 mg; $7.2 \mathrm{mg} ; 14.4 \mathrm{mg}$ ), kemudian masing-masing ekstrak yang telah ditimbang dimasukan dalam labu ukur $10 \mathrm{~mL}$ disonifikasi sampai homogen selama 120 menit. Setelah homogen, masingmasing dosis ekstrak dimasukkan ke dalam botol sampel dan diberi label.

\section{Pembuatan Larutan Aloksan}

Dosis induksi aloksan pada tikus adalah $120 \mathrm{mg} / \mathrm{kgBB}$, maka jumlah aloksan yang diberikan pada tikus dengan berat $100 \mathrm{~g}=(100 \mathrm{~g} / 1000 \mathrm{~g}) \times 120 \mathrm{mg} / \mathrm{kgBB}=$ $12 \mathrm{mg} / \mathrm{tikus} \quad 100 \mathrm{~g}$. Serbuk aloksan monohidrat dilarutkan dengan cara diencerkan menggunakan larutan aquades. Konsentrasi larutan induksi $12 \mathrm{mg} / \mathrm{ml}$.

\section{Pembuatan Larutan Metformi}

Berdasarkan tabel konversi perhitungan dosis untuk berbagai jenis hewan uji dari berbagai spesies dan manusia, maka konversi dosis manusia dengan berat badan $70 \mathrm{~kg}$ pada tikus dengan berat badan $200 \mathrm{~g}$ adalah 0,018 (Ngatidjan, 1991). Dosis metformin yang dipakai untuk orang dewasa adalah $500 \mathrm{mg}$, jadi dosis untuk tikus $200 \mathrm{~g}$ adalah $9 \mathrm{mg}$. Untuk tikus dengan berat 100 gram adalah $4,5 \mathrm{mg}$.

Timbang tablet metformin yang sudah digerus halus sebanyak $45 \mathrm{mg}$. Kemudian dimasukkan ke dalam labu $10 \mathrm{ml}$ dan ditambahkan aquades sampai $10 \mathrm{ml}$, dan kocok sampai homogen.

\section{Pemberian Larutan Aloksan}

Tikus dibuat menjadi diabetes dengan menginjeksikan larutan aloksan melalui interperitonial. Aloksan diberikan sekali sebanyak $1 \mathrm{ml}$. Proses penyimpanan sampai proses penyuntikan aloksan dilakukan pada suhu dingin supaya aloksan tidak rusak (Sujono dan Munawaroh, 2009). 


\section{Pemberian Ekstrak Daun Sesewanua}

Pemberian perlakuan untuk penelitian ini masing-masing konsentrasi menggunakan 3 Tikus untuk tiap kelompok hewan uji. Ekstrak daun sesewanua diberikan sesuai dosis perlakuan yaitu $1 \mathrm{~mL}$ pada setiap tikus untuk masing-masing konsentrasi secara oral menggunakan alat penyekok oral (Sonde) dengan dispo dua hari sekali selama 14 hari.

\section{Pemberian Larutan Metformin}

Pemberian perlakuan untuk kelompok pembanding dengan 3 ekor tikus sebagai hewan uji. Larutan Metformin diberikan sesuai dosis yaitu $1 \mathrm{~mL}$, perlakuan secara oral menggunakan alat penyekok oral (Sonde) dengan dispo setiap hari sekali untuk satu ekor tikus selama 14 hari.

\section{Pemeriksaan Gula Darah}

Darah diambil pada bagian ekor dengan cara memotong ekor tikus dan diukur kadar gula darah dengan alat glukometer accu check.

\section{HASIL DAN PEMBAHASAN}

Hewan uji yang digunakan dalam penelitian ini adalah tikus putih jantan galur wistar karena karakteristik genetik dan biologisnya mirip dengan manusia, dan untuk pemilihan kelamin dipilih jantan karena tidak terpengaruh adanya hormon. Tikus diaklimatisasi selama dua minggu bertujuan agar tikus bisa beradaptasi dengan lingkungan dan tidak stres.

Sebelum melakukan pengujian, semua tikus ditimbang berat badannya agar bisa menghitung dosis yang akan diberikan. Berat badan rata - rata dari semua tikus adalah 95,67 g yang dibulatkan menjadi 100 g. Kemudian semua tikus diperiksa kadar gula darah awal dan diperoleh data kadar gula darah awal tikus berada pada keadaan normal dengan ratarata 79,67 - 90,67 mg/dL. Kusumawati
(2004), menyatakan bahwa kadar gula darah normal pada tikus berada pada 50$135 \mathrm{mg} / \mathrm{dL}$.

Pada kelompok kontrol negatif, tikus dibuat menjadi diabetes yang bertujuan agar dapat mengetahui pengaruh metabolisme terhadap penurunan kadar gula darah tikus dan juga dapat mengetahui penurunan kadar gula darah normal tikus selama melakukan penelitian. Hasil pengukuran gula darah kemudian dibandingan dengan kelompok yang lain. Kadar gula darah pada kelompok negatif mengalami kenaikan dan penurunan yang tidak terlalu signifikan, tetapi berada pada keadaan normal, dengan kata lain metabolisme tidak membantu menurunkan kadar gula darah tikus menjadi normal.

Pada hari ke tiga (T3) setelah diinduksi aloksan, hasil rata-rata yang didapatkan adalah kelompok kontrol positif, kontrol negatif, D1, D2, dan D3 semuanya mengalami kenaikan gula darah antara 99-179,33 mg/dL, hal ini disebabkan karena aloksan menghambat glukosa yang disebabkan karena sekresi insulin melalui spesifik penghambat glukokinase,hasil sensor glukosa sel beta akan menyebabkan keadaan diabetes pada tikus.

Pada kontrol positif yang diberikan metformin kadar gula darah mengalami penurunan yang besar. Pemilihan metformin sebagai pembanding dianggap tepat karena mekanisme kerja metformin dalam tubuh dengan memperbaiki sensitivitas hepar dan jaringan perifer terhadap insulin tanpa mempengaruhi sekresi insulin. Efek ini terjadi karena adanya aktivitas kinase di sel (AMPactivated kinase). Metformin meningkatkan pemakaian glukosa oleh sel usus sehingga menurunkan glukosa darah dan juga menghambat absorbs glukosa di usus sesudah asupan makanan (Soegondo, 2006). 
Pada D1 yang diberikan ekstrak daun sesewanua dengan dosis 200mg (3,6 $\mathrm{mg} / \mathrm{mL}$ ) hasil pengukuran gula darah ratarata menunjukkan penurunan kadar gula darah pada $\mathrm{T} 4$, yang sebelumnya kadar gula darah tikus rata-rata $132,33 \mathrm{mg} / \mathrm{dL}$ pada $\mathrm{T} 3$, menjadi 106,67 $\mathrm{mg} / \mathrm{dL}$ pada $\mathrm{t} 4$, dan pada T8 menjadi $90,33 \mathrm{mg} / \mathrm{dL}$. Kadar gula darah mengalami kenaikkan lagi menjadi $102,33 \mathrm{mg} / \mathrm{dL}$ pada T10 dan mengalami penurunan pada T12 menjadi $87,33 \mathrm{mg} / \mathrm{dL}$ dan mengalami sedikit kenaikkan menjadi $87,67 \mathrm{mg} / \mathrm{dL}$ pada T14. Dengan demikian dapat dikatakan bahwa ekstrak daun

Tabel 1. Rata-rata Kadar Gula Darah Tikus Putih Jantan Galur Wistar

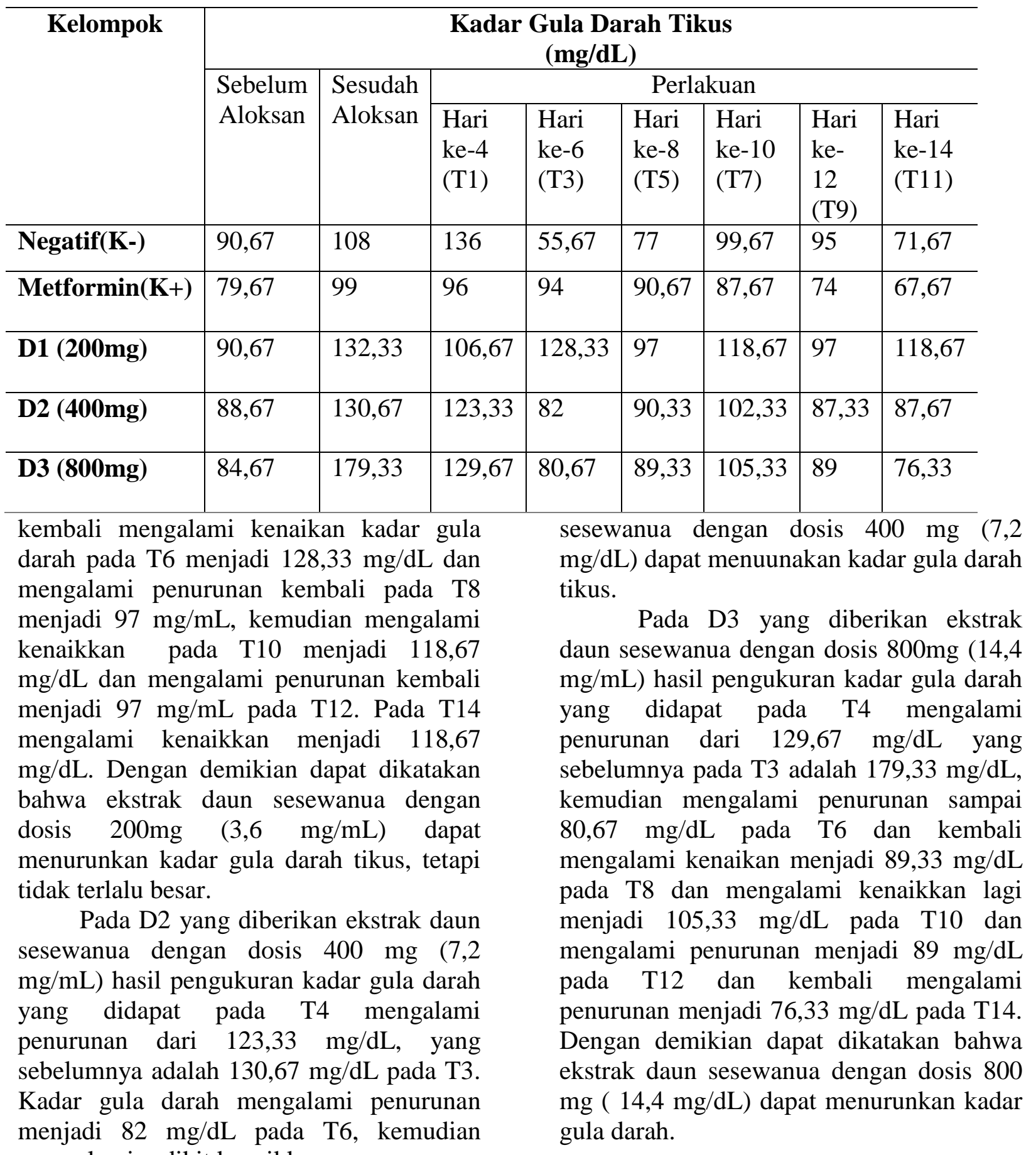




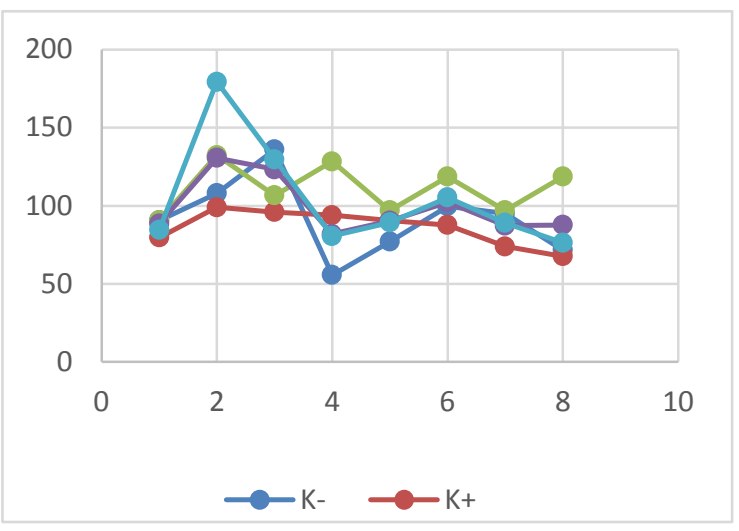

Gambar 1. Rata-rata peningkatan dan penurunan kadar gula darah tikus

Pada D1 (200mg), D2 (400mg), dan D3 (800mg) mengalami penurunan kadar gula darah. Hal ini menunjukkan bahwa ekstrak daun sesewanua dapat memberikan efek penurunan kadar gula darah. Penurunan kadar gula darah yang paling besar pada D3 (800mg) yang berarti semakin tinggi dosis yang diberikan maka penurunan kadar gula darah semakin besar. Penurunan kadar gula darah yang dihasilkan dari ekstrak daun sesewanua disebabkan oleh kandungan senyawa Flavonoid yang merupakan salah satu antioksidan.

Aktivitas antioksidan mampu menangkap radikal bebas penyebab kerusakan sel beta pankreas dan menghambat kerusakan sel beta pankreas, sehingga sel beta yang tersisa masih tetap berfungsi. Antioksidan tersebut diperkirakan mampu melindungi sejumlah sel-sel beta yang tetap normal, sehingga memungkinkan terjadinya regenerasi sel-sel beta yang masih ada melalui proses mitosis atau melalui pembentukan pulau baru dengan cara proliferasi dan diferensiasi endokrin dari sel-sel ductal dan ductular (Suryani et al, 2013).

Pada uji statistic Kruskal Wallis dapat dilihat bahwa kelima grup memiliki bentuk sebaran yang berbeda-beda, sehingga pada uji Kruskal Wallis yang bisa diinterpretasikan hanya perbedaan rata-rata. Pada hasil uji Kruskal Wallis rata-rata skala paling tinggi terdapat pada kelompok D1. Nilai $P$ value ditunjukkan oleh nilai Asymp. Sig. Pada hasil ditunjukkan nilai $\mathrm{P}$ Value sebesar 0,053 di mana lebih dari 0,05 yang berarti H0 diterima yang berarti tidak terdapat perbedaan yang bermakna antara ekstrak daun sesewanua dengan metformin. Hal ini menunjukkan bahwa ekstrak daun sesewanua memiliki efektivitas terhadap penurunan kadar gula darah tikus yang hampir sama dengan metformin

\section{KESIMPULAN}

Berdasarkan hasil penelitian dapat simpulkan bahwa, Ekstrak Daun Sesewanua (Clerodendron squamatum Vahl.) dapat memberikan efek anti diabetes terhadap tikus putih jantan galur wistar (Rattus norvegicus $L$.) yang diinduksi aloksan.

\section{SARAN}

Perlu diadakan penelitian lebih lanjut untuk menentukkan dosis efektif dan dosis maksimum dari ekstrak daun sesewanua untuk menurunkan kadar gula darah.

\section{DAFTAR PUSTAKA}

Buraerah, H. 2010. Analisis Faktor Risiko Diabetes Melitus tipe 2 di Puskesmas Tanrutedong, Sidenreng Rappang. Jurnal Ilmiah Nasional. 35:(4).

Harbone. 1987. Metode Fitokimia Penuntun Cara Modern Menganalisis. ITB press, Bandung.

Huliselan, Y., Runtuwene, M., Wewengkang, D. 2015. Aktivitas Antioksidan Ekstrak Etanol, EtilAsetat, dan $n$-Heksan dari sesewanua (Clerodendron squamatum Vahl.). Jurnal Ilmiah Farmasi. 4:(3), 155-156 
Iskandar. 2010. Metodologi Penelitian Pendidikan dan Sosial (Kuantitatif dan Kualitatif). Jakarta: Gaung Persada Press (GP Press).

Kusumawati, D. 2004. Bersahabat dengan Hewan Coba. Yogyakarta : Gadjah Mada University Press.

Perkeni. 20011. Konsensus Pengelolaan dan Pencegahan Diabetes Mellitus Tipe 2 di Indonesia. Perkumpulan Endokrinologi Indonesia. Jakarta: PB PERKENI

Sujono T.A., Munawaroh, P. 2009. Interaksi Quercetin Dengan Tolbutamid: Kajian Terhadap Perubahan Kadar Glukos Darah Tikus Jantan Yang Diinduksi Aloksan. Jurnal Penelitian Sains \& Teknologi. 10: (2), 121-129.

Suryani, N., Murdani, P. (2013). Jurnal Megister Kedokteran Keluarga. 1 (1). 67- 69 